\title{
BORON NITRIDE COATINGS AND MATERIALS FOR USE IN AGGRESSIVE
} ENVIRONMENTS

T. M. BESMANN, W. Y. LEE, * J. P. YOUNG, and H. XIAO

Oak Ridge National Laboratory, Oak Ridge, TN 37831-6063, tmb@ornl.gov

ABSTRACT

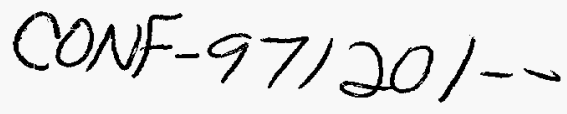

Boron nitride coatings and structures have demonstrated significant resistance to many corrosive environments. These coatings may have application in the protection of sensors needed for measuring a variety of properties such as temperature and chemistry. In addition, boron nitride materials may offer advantages as structural materials in high temperature materials processing. In this study, $\mathrm{BN}$ is assessed for use in aluminum smelting.

\section{INTRODUCTION}

Hexagonal structure BN (hex-BN) has found substantial utility in a variety of harsh environments such as III-V compound semiconductor processing [1], interface coatings for high temperature ceramic composites [2], and general purpose high temperature crucibles [3]. As a result, hex-BN was considered for use as a structural/protective material in aluminum smelting. There are few more aggressive environments than that of aluminum smelting, where molten cryolite has proved to be an excellent solvent for almost any material. The identification of a material relatively stable in cryolite would be of great value as thermocouple sheaths and for various other components in an aluminum smelting pot line. In particular, transparent or translucent hex-BN coatings are desirable for protecting windows of optical probes such as Raman sensors, which is the goal of the current work.

Boron nitride coatings, and even crucibles and other forms, are manufactured using chemical vapor deposition. Typically, the hex-BN is deposited on a substrate from the reaction of vapor phase $\mathrm{BCl}_{3}$ and $\mathrm{NH}_{3}$ at elevated temperatures. Lee et al [4] have described the effect of deposition temperature on the character of the deposited hex-BN. The graphite-like structure of the material is highly crystalline and anisotropic when obtained at temperatures of $\sim 2000^{\circ} \mathrm{C}$ or higher. This is desirable as it imparts a greater degree of environmental stability. Unfortunately, such high temperature hex-BN is white and opaque. It has been observed that lower deposition temperatures $\left(<1300^{\circ} \mathrm{C}\right)$ yield films that are transparent/translucent. At these temperatures the deposited hex-BN has a more disordered crystal structure with randomly oriented, turbostratic grains. Total pressure during deposition is also seen to effect crystallinity.

The object of the current work is to determine the stability of hex-BN in an aluminum smelting environment, including the influence of its preparation conditions on that stability.

${ }^{*}$ Current address: Department of Materials Science and Engineering, Stevens Institute of Technology, Castle Point on Hudson, Hoboken, NJ 07030

DUTMEUTION OF MIS DOCUMENT IS UNLMMTH

"The submitted manuscript has been authored by a contractor of the U.S. government under contract No. DE-AC05-960R22464. Accordingly, the U.S. Government retains a nonexclusive, royalty-free license to publish or reproduce the published form of this contribution, or allow others to do so, for U.S. Government purposes." 


\section{DISCLAIMER}

This report was prepared as an account of work sponsored by an agency of the United States Government. Neither the United States Government nor any agency thereof, nor any of their employees, make any warranty, express or implied, or assumes any legal liability or responsibility for the accuracy, completeness, or usefulness of any information, apparatus, product, or process disclosed, or represents that its use would not infringe privately owned rights. Reference herein to any specific commercial product, process, or service by trade name, trademark, manufacturer, or otherwise does not necessarily constitute or imply its endorsement, recommendation, or favoring by the United States Government or any agency thereof. The views and opinions of authors expressed herein do not necessarily state or reflect those of the United States Government or any agency thereof. 


\section{DISCLAIMER}

Portions of this document may be illegible electronic image products. Images are produced from the best available original document. 


\section{THERMOCHEMICAL ANALYSIS}

The stability of $\mathrm{BN}$ in cryolite was first assessed via thermochemical analysis. The commercial computer code ChemSage was used to determine the chemical equilibrium state of $\mathrm{BN}$ with an assumed cryolite melt $\left(3 \mathrm{NaF} \cdot \mathrm{AlF}_{3}\right)$ containing $10 \% \mathrm{Al}_{2} \mathrm{O}_{3}$ in an ideal solution. The thermodynamic simulations were performed for $1027^{\circ} \mathrm{C}$ and an oxygen partial pressure of $10^{-28}$ $\mathrm{kPa}$. The thermodynamic analysis indicated that $\mathrm{BN}$ would be stable under these conditions, not forming compounds with the components of the melt.

\section{EXPERIMENTAL}

Initial studies were performed with commercial hex-BN plates $(25.4 \mathrm{~mm} \times 12.7 \mathrm{~mm} \times 3.2$ $\mathrm{mm}$ ) (Advanced Ceramics, Cleveland, $\mathrm{OH}$ ). They are produced by chemical vapor deposition onto graphite substrates at $\sim 2000^{\circ} \mathrm{C}$, with the hex-BN easily separating from the graphite upon cooling. The material possesses a high degree of crystallinity and is highly textured with the basal planes aligned with the substrate surface.

Samples of this material were tested by partially submerging them in molten cryolite ( $3 \mathrm{NaF} \cdot \mathrm{AlF}_{3}-12 \% \mathrm{Al}_{2} \mathrm{O}_{3}-5 \% \mathrm{CaF}_{2}$ ) at $943^{\circ} \mathrm{C}$ in air or $\mathrm{CO}_{2}$ atmosphere. After cooling to room temperature samples were easily removed from the cryolite bath.

Low-temperature hex-BN was prepared at our laboratory via low-pressure CVD from $\mathrm{BCl}_{3}$ and $\mathrm{NH}_{3}$ at $1100^{\circ} \mathrm{C}$ on silica and sapphire substrates. Carbon coatings were similarly prepared from propylene.

The samples were characterized by $x$-ray diffraction (XRD, Scintag PAD V, Cupertino, CA), $x$-ray photoelectron spectroscopy (XPS, 5600 Physical Electronics, Eden Prairie, MN), and electron microprobe (JEOL 733 Superprobe, Peabody, MA).

\section{RESULTS}

The commercial hex-BN plates were exposed to the cryolite bath for $52 \mathrm{~h}$ and $120 \mathrm{~h}$. After $52 \mathrm{~h}$ in either air or $\mathrm{CO}_{2}$ atmospheres there was no evidence of attack seen visually or in the XPS analysis. After $120 \mathrm{~h}$ in the $\mathrm{CO}_{2}$ atmosphere, however, there was visible recession of the hex-BN surface that was submerged in the cryolite. Table I shows the results of the XPS analysis of this sample. Since XPS is a surface sensitive technique, the surface was sputtered to obtain sub-surface compositional information. It is estimated that sputtering removes $20 \mathrm{~nm} / \mathrm{min}$ of the hex-BN.

From Table I the typical environmental contamination by carbon is seen on the unsputtered surface of the hex-BN. After sputtering the residual cryolite constituents are still seen in the hex-BN and may be indicative of the dissolution of the hex-BN.

Another commercial hex-BN sample was provided to Kaiser Aluminum Materials Laboratory (Spokane, WA) for testing in an electrolytic cell. Post-exposure electron microprobe analysis of a polished cross-section of the surface revealed that the hex-BN was covered by $\mathrm{a} \sim 15 \mu \mathrm{m}$ thick carbon-rich layer which may have been produced prior to or during exposure to the cryolite (Fig. 1). At points, the carbon-rich layer also intrudes into the cryolite to depths of over $100 \mu \mathrm{m}$. The layer was observed to be a coherent and adherent film on the hex-BN, with remnants of cryolite attached to the exterior surface. As can be seen from Fig. 1, there appear to be two differing areas of contrast in the film. Electron microprobe analysis indicates that the composition in both of these areas are similar, 
Table I. Composition (atomic \%) of commercial hex-BN from XPS after $120 \mathrm{~h}$ exposure to cryolite in $\mathrm{CO}_{2}$ environment.

$\begin{array}{ccccccccccc}\begin{array}{c}\text { Sputter } \\ \text { Time } \\ (\mathrm{min} .)\end{array} & \begin{array}{c}\text { Depth } \\ (\mathrm{nm})\end{array} & \mathrm{B} & \mathrm{N} & \mathrm{Al} & \mathrm{Na} & \mathrm{F} & \mathrm{O} & \mathrm{C} & \mathrm{Cl} & \mathrm{Si} \\ 0 & & & & & & & & & & \\ 0.5 & 10 & 37 & 10 & 2.1 & & & 13 & 60 & 1.6 & 1.8 \\ 2.0 & 40 & 44 & 37 & 2.7 & 0.7 & 2.1 & 7.4 & 16 & 1.0 & 1.6 \\ 5.0 & 100 & 46 & 43 & 0.6 & 0.8 & 1.1 & 4.6 & 9.2 & 0.9 & 0.8 \\ & & & & & & & & & & \end{array}$

consisting of 70-80 atom \% carbon with the darker region having $\sim 9$ atom $\%$ boron and the lighter region $\sim 2$ atom $\%$. The regions also contain some residual cryolite components. At this point it is unclear as to what mechanism caused the formation of the film, although it suggests that carbon-coated hex-BN appears to be more stable in cryolite than is uncoated hex-BN.

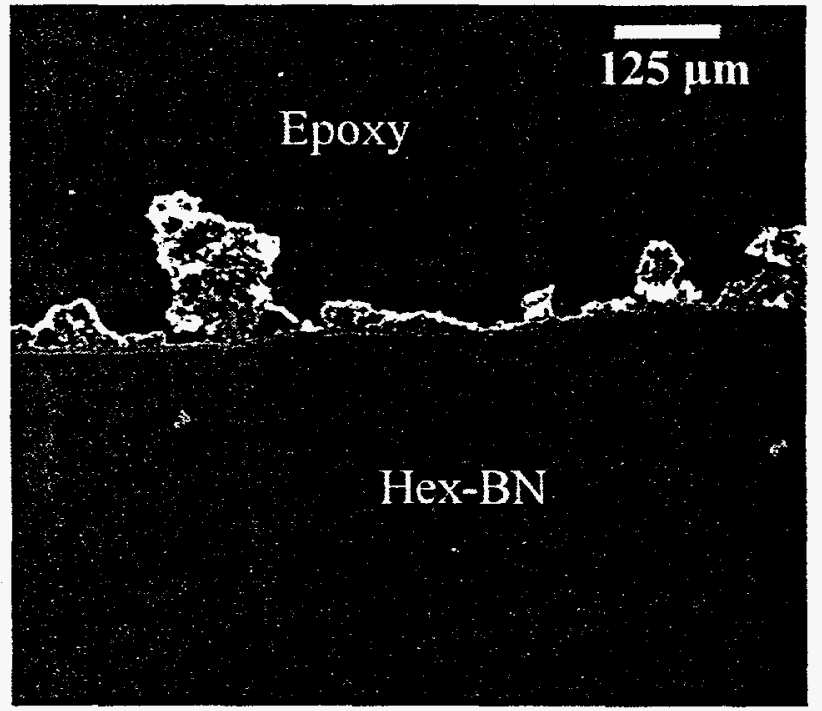

(a)

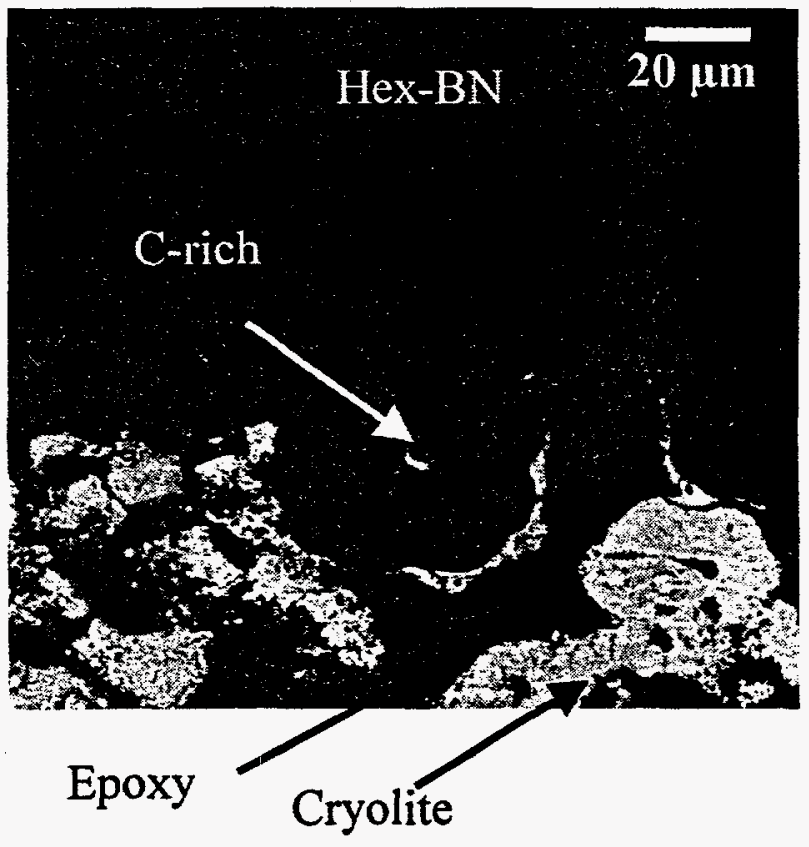

(b)

Fig. 1. SEM image of a polished cross-section of commercial, high-temperature hex-BN (a) before and (b) after exposure to a Kaiser Aluminum electrolytic cell.

The CVD hex-BN prepared on silica substrates at ORNL was deposited at $1100^{\circ} \mathrm{C}$, and therefore was expected to have less crystallographic order. This was confirmed by XRD which indicated two broad peaks at $2 \theta$ values around $20-30^{\circ}$ and $40^{\circ}-48^{\circ}$, which correspond to the random stacking sequence of the hex-BN basal planes. Previously reported transmission electron microscopy of similar coatings revealed that they consist of $10-100 \mathrm{~nm}$ elongated hex-BN grains 
embedded in an amorphous matrix [5].

The coatings deposited on the silica substrates were largely transparent. After several days, however, the silica windows $(\sim 3 \mathrm{~mm}$ dia. $\mathrm{x} \sim 1 \mathrm{~mm}$ thick $)$ developed cracks that initiated at the coating-silica interface. Eventually the windows fractured into several pieces. In addition, even very short-term exposure of the coatings to a cryolite melt resulted in their dissolution.

In order to determine if an intentionally deposited carbon coating would protect the lowtemperature hex-BN from dissolution in cryolite, a sample was prepared of CVD hex-BN overcoated with carbon with sapphire as the substrate. Figure 2 is an electron back-scatter image of a carbon-coated low-temperature CVD hex-BN after exposure to cryolite for 52h. The sapphire substrate is seen at the bottom of the image and appears unaffected by the exposure. From electron microprobe analysis there lies between the sapphire and the deposited hex-BN a thin carbon layer. This layer was not intentionally deposited on the sapphire, but may have formed during heat-up in the furnace in preparation for deposition of the hex-BN. The furnace consists of a graphite heating element and graphite internals, and while heat-up is under inert gas, there is a short period in which hydrogen flows through the furnace prior to admission of the $\mathrm{BCl}_{3}$ and $\mathrm{NH}_{3}$ gases. Thus the carbon layer could have formed due to chemical transport of carbon from the furnace internals via formation of hydrocarbons or by direct evaporation/condensation.

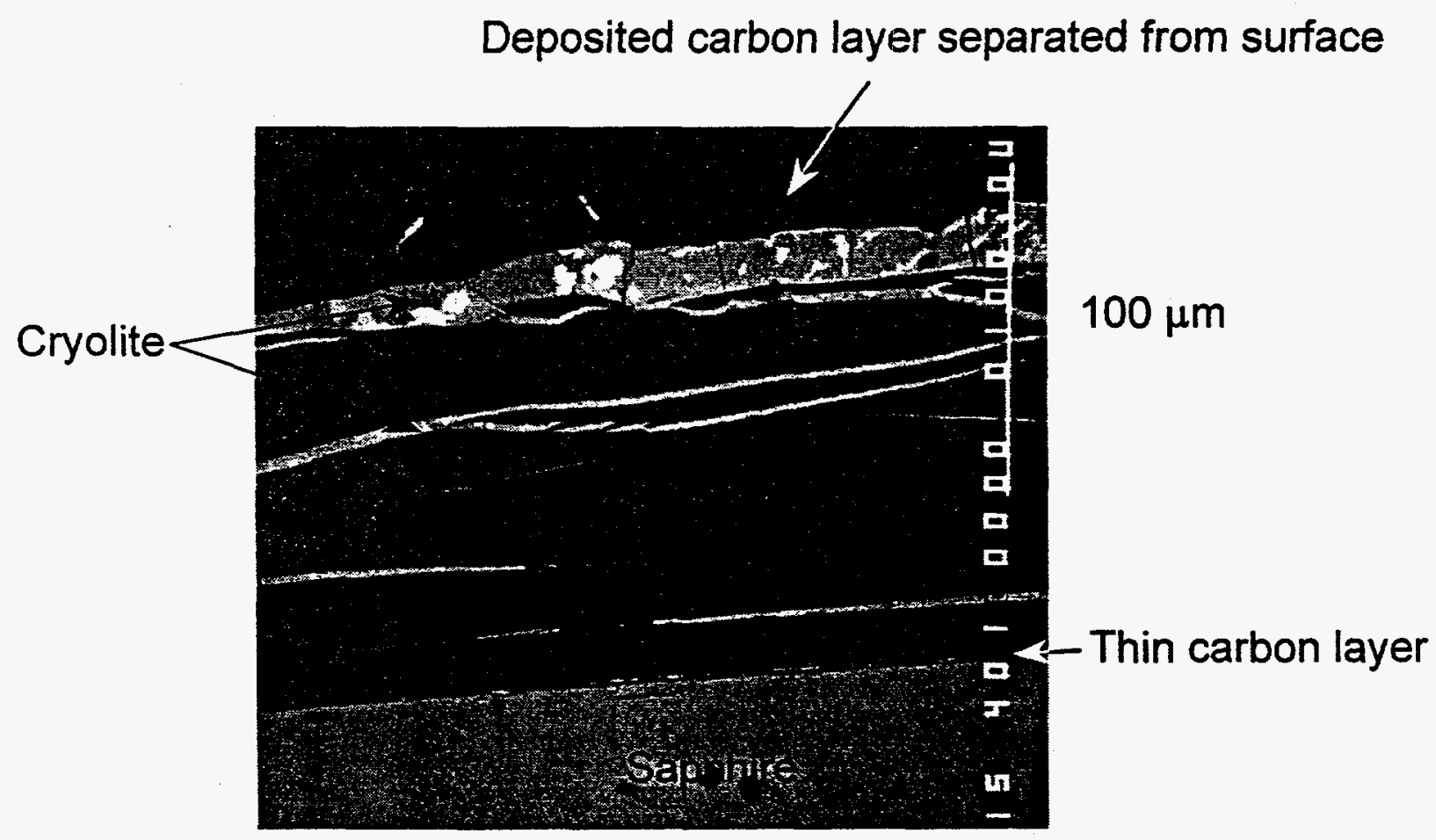

Fig. 2. Carbon-coated hex-BN after exposure to cryolite.

Immediately above the thin carbon layer is the deposited hex-BN which is $\sim 100 \mu \mathrm{m}$ in thickness. Lateral cracks can be seen in the hex-BN, possibly aligned with the weak crystallographic planes of the phase. These cracks contain cryolite that infiltrated into these 
regions and froze on cooling. The darker, major cryolite composition appears to be more sodium-rich, containing approximately 11 atomic- $\%$ carbon. The lighter inclusions contain calcium and almost half the carbon of the darker areas. In the half of the hex-BN coating thickness closest to the external surface are seen roughly circular, lighter inclusions of the order of 2-3 $\mu \mathrm{m}$ in diameter. These are hex-BN containing $\sim 4$ atomic- $\%$ aluminum and $\sim 11$ atomic- $\%$ oxygen. It is likely that these are areas in which the cryolite has reacted with the $\mathrm{BN}$, partially oxidizing the phase.

On the external surface of the hex-BN can be seen the deposited carbon layer, which is $\sim 6$ $\mu \mathrm{m}$ in thickness. This layer, however, has separated from the hex-BN, and in this image is not in contact with the rest of the sample. Lying on the hex-BN surface is a layer of cryolite, and between the cryolite and the deposited carbon is the epoxy used for mounting the specimen. It is possible that the cryolite undercut the carbon during exposure.

\section{DISCUSSION}

Although the chemical thermodynamic assessment indicated that hex-BN should be stable in cryolite, the experimental evidence is less clear. The recession of high-temperature hex$\mathrm{BN}$ in the cryolite melt indicates that it is soluble in cryolite.

The cause of the cracking of the silica substrate windows may be related to the significant amorphous phase content of the samples. Whereas hex-BN has a very low modulus, the same may not be true for the amorphous, glassy phase. The coating may therefore be fairly brittle and offer sites for crack initiation due to the difference in thermal expansion coefficient between the coating and very low coefficient for silica.

The preliminary finding that carbon coatings may protect a hex-BN coating from attack by cryolite is very interesting. No mechanism has been postulated for this behavior, although it may related to control of oxygen potential in the vicinity of coatings. A unity carbon activity will drive the oxygen potential to very low values, thus preventing wholesale oxidation of the hex-BN. Arguments for the stability of the thin carbon film in a cryolite melt have not been developed.

\section{CONCLUSIONS}

The use of hex-BN in aluminum smelting will require substantially more study. Initial efforts reveal some stability of high-temperature hex-BN, although recession is noted. The accidental discovery that carbon films may act to stabilize hex-BN in cryolite has been confirmed through deliberate experiment. A cogent theory for this behavior has yet to emerge.

\section{ACKNOWLEDGMENTS}

The authors would like to acknowledge R. A. Lowden and S. D. Nunn for reviewing the manuscript. R. A. Czikall and M. A. Wybomey of Kaiser Aluminum Materiais Laboratory, Spokane, WA are recognized for their efforts in the pot-line exposure testing. This research was supported by the U. S. Department of Energy, Office of Energy Efficiency and Renewable Energy, Office of Industrial Technologies and the Laboratory Technology Research Program, Office of Energy Research under contract DE-AC05-96OR22464 with Lockheed Martin Energy Research Corporation. 


\section{REFERENCES}

1. H. Tanji, K. Monden, M. Ide in $10^{\text {th }}$ Int. Conf. CVD, edited by G. W. Cullen (The Electrochemical Society, Pennington, NJ 1987), p. 562-569.

2. R. A. Lowden, K. L. More, O. J. Schwarz, and N. L. Vaughn, in Proc. High Temperature Ceramic Matrix Composites, edited by R. Naslain, J. Lamon, and D. Doumeingts (Woodhead Pub. Ltd., Cambridge, UK 1993), p. 345.

3. N. J. Archer, High Temperature Chemistry of Inorganic and Ceramic Materials, edited by F. P. Glasser and P. E. Potter (The Chemical Society, London, UK 1976), p. 167.

4. W. Y. Lee, W. J. Lackey, and P. K. Agrawal, A. Am. Ceram. Soc. 74 (10), p. 2642 (1991).

5. K. L. More, personal communication, 1997. 